\title{
PENERAPAN REALISTIC MATHEMATICS EDUCATION DALAM PEMBELAJARAN MEMBACA DIAGRAM BATANG DAN GARIS SISWA SMP KELAS VII
}

\author{
Achmad Badrun Kurnia $^{\text {a) }}$, Eny Suryowati ${ }^{\text {b) }}$ \\ Program Studi Pendidikan Matematika STKIP PGRI Jombang \\ a)badrun_bbest@yahoo.co.id \\ b)eny_3v9@ymail.com
}

\begin{abstract}
ABSTRAK
Representasi dalam proses pembelajaran matematika mempunyai fungsi yang sangat penting. Diagram sebagai salah satu representasi, penting untuk dipahami. Di kelas VII SMP, menyajikan dan membaca data juga diajarkan dalam bab Statistik. Tujuan utama dari penelitian ini adalah untuk memberikan kontribusi pada praktek pembelajaran diagram, yang difokuskan pada aktivitas membaca diagram. Peneliti tertarik untuk mengetahui bagaimana siswa berusaha untuk menemukan arti dari sebuah diagram batang dan garis. Oleh karena itu, design research, dipilih sebagai jenis dan pendekatan penelitian. Subjek dari penelitian ini adalah siswa kelas VII A SMP Madinatul Ulum, Jombang, Jawa Timur tahun ajaran 2014/2015. Sebuah HLT (Hypothetical Learning Trajectory) telah dihasilkan dan diujicobakan, dan selanjutnya telah dianalisis dengan cara membandingkan HLT dengan proses belajar siswa yang sesungguhnya. (retrospective analysis). Data yang dikumpulkan dalam peneltian ini berbentuk hasil kerja siswa dan proses pembelajaran yang divideokan. Dari hasil analisis, disimpulkan kemampuan siswa di awal pembelajaran berada diantara Idiosyncratic dan Transitional level. Akan tetapi sulit untuk memastikan berada di level mana kemampuan siswa tersebut, dikarenakan apa yang mampu mereka pikirkan berbeda dengan yang telah mereka tulis. Dengan diskusi kelas, kemampuan mereka dalam membaca diagram telah meningkat. Mereka mulai membaca "between the data" dan "beyond the data". Pada akhir pembelajaran, analisis data telah mengantarkan pada kesimpulan bahwa siswa mulai membaca diagram pada Quantitative level.
\end{abstract}

Kata kunci : membaca diagram, diagram batang, diagram garis

\begin{abstract}
The role of a representation in teaching mathematics is importantce, and diagrams or graphs as one of representations are important to be understood. In the $7^{\text {th }}$ grade of junior secondary school, representing and reading data is taught in Statistics topics. This research aims to contribute to teaching practice on graphs, focused on activities to read information on graphs. The researchers were interested to know how students are struggling to find the meaning of bar and line graphs. Therefore, design research, was chosen as research design and the subjects in this research were $7^{\text {th }}$ grade students of SMP Madinatul Ulum, Jombang, East Java 2014/2015. An HLT (Hypothetical Learning Trajectory) has been resulted, tried out and analyzed by comparing the HLT with students' actual learning process (retrospective analysis). The collected data in this research were in the form of students' work and the video-recorded learning process. From the analysis, it was found that the students' initial understanding was in Idiosyncratic and Transitional level. However, it is difficult to ensure in which level the students are, because what they have though was different from what they have written. By class discussion, their ability in reading graphs can be improved. They have started to read "between the data" and "beyond the data". As an ending point, it can be concluded that students have moved to Quantitative level in reading data presented in the given graphs.
\end{abstract}

Keywords: reading graphs, bar graphs, line graphs 


\section{Pendahuluan}

Penggunaan sebuah representasi dalam proses pengajaran matematika sangatlah penting sejak di kelas bawah sekolah dasar. Sebuah representasi dapat digunakan sebagai alat berpikir dan belajar oleh siswa seperti halnya guru menggunakanya sebagai alat untuk mengajar. Prain dan Waldrip seperti yang dikutip oleh Meredith, et. al. (2007) berpendapat bahwa siswa kelas 4 sampai kelas 6 yang terbiasa menggunakan bermacam-macam representasi mempunyai pemahaman konseptual yang lebih baik daripada siswa yang tidak atau jarang menggunakan representasi. Hal ini dikarenakan representasi adalah alat yang sangat berguna untuk membangun pemahaman dan untuk mengkomunikasikan informasi.

Fey seperti yang dikutip dalam Ersoy (2004) menyatakan bahwa ada tiga macam representasi dalam matematika yang dapat digunakan untuk mendeskripsikan sebuah data, yaitu berupa representasi dalam bentuk tabel, aljabar, dan grafik atau diagram. Sebagai salah satu dari representasi dalam matematika, diagram mempunyai fungsi yang penting dalam pemecahan masalah aritmetika dan aljabar dan dalam merepresentasikan hubungan antar variabel (Ates \& Stevens, 2003). Hubungan matematis yang ditunjukan oleh diagram biasanya tidak mudah dipahami jika disajikan dalam bentuk numerik (Arkin dan Colton seperti yang dikuti dari Ersoy, 2004). Oleh karena itu, cukup untuk mengatakan bahwa, siswa sangatlah perlu untuk memahami dan mengerti diagram sebagai sebuah alat untuk merepresentasikan dan mengkomunikasikan ide-ide tertentu dalam matematika.

Untuk memahami diagram, siswa harus mempelajari bagaimana caranya untuk mengkonstruksi dan menginterpretasikan diagram. Mengkonstruksi diagram merujuk kepada membuat diagram atau mem-plot titik-titik dari data, dan memulai dari data mentah sampai pemilihan label pada kedua sumbu, pemilihan skala, dan pengidentifikasian satuan (Leinhardt, Zaslavsky \& Stein 1990). Sementara itu, menginterpretasikan diagram merujuk pada aktifitas dimana siswa memahami arti dari data yang direpresentasikan oleh diagram (Leinhardt, Zaslavsky \& Stein, 1990). Hal ini mengisyaratkan bahwa banyak sekali ide dan skill yang harus dikuasai oleh siswa dalam kaitanya dengan mengkonstruksi dan menginterpretasikan sebuah diagram.

Beberapa penelitian tentang diagram sudah dilakukan oleh penelitipeneliti terdahulu dan sebagian besar 
penelitian tersebut difokuskan pada kesalahan siswa, sumber kesalahan siswa, dan kesulitan siswa baik dalam mengkonstruksi maupun menginterpretasikan sebuah diagram. Leinhardt, Zaslavsky, \& Stein (1990) menyatakan bahwa tidak peduli seberapa banyak atau sering seorang siswa mengetahui diagram, beberapa peneliti menunjukan bahwa siswa dari segala rentang usia mempunyai kesulitan dalam memahami informasi yang tertulis di diagram. Siswa seringkali bisa dengan mudah menggambar diagram, akan tetapi tetap menunjukan hasil yang kurang memuaskan dalam menginterpretasikan informasi yang terkandung dalam sebuah diagram (Parmar \& Signer, 2005).

Di kurikulum matematika di Indonesia, diagram diperkenalkan pertama kali di kelas VI semester kedua (pada K13 di kelas IV), dan diajarkan kembali dengan lebih ditekankan pada statistik meliputi rataan hitung, nilai tengah dan modus dari suatu data di kelas VII SMP. Tidaklah menjadi jaminan, siswa kelas VII SMP akan mudah dalam mempelajari diagram batang dan garis dikarenakan pengetahuan yang mereka dapatkan sebelumnya di kelas enam. Hal ini dikarenakan, kadangkala dalam praktenya, ide-ide mendasar tentang diagram tidak diajarkan oleh guru matematika. Pendekatan yang digunakan oleh guru, sebagian besar masih bersifat structuralistic daripada realistic. Oleh karena itu, merupakan sebuah tantangan tersendiri untuk meningkatkan pendidikan matematika di Indonesia dengan menerapkan pendekatan Realistic Mathematics Education (RME) atau Pendidikan Matematika Realistik Indonesia (PMRI).

Dengan mempertimbangkan isuisu yang disebutkan di atas, perlu kiranya dilakukan penelitian tentang penerapan realistic mathematics education dalam pembelajaran diagram batang dan garis siswa SMP kelas VII. Dimana pada kali ini hanya akan difokuskan pada aktivitas membaca diagram, yang merupakan sebagian kecil dari penelitian yang lebih luas, membaca dan mengkontruksi diagram. Bagaimanakah kemampuan siswa dalam membaca informasi pada diagram batang dan garis dapat ditingkatkan menjadi tujuan dalam penelitian ini.

\section{Definisi Diagram sebagai Sebuah} Representasi

Penelitian di pendidikan matematika menunjukan kepada kita bahwa pemahaman siswa terbangun ketika guru menggunakan berbagai macam representasi (seperti, gambar, tabel, diagram dan persamaan) untuk mengajarkan ide-ide yang kompleks 
(Meredith, 2007). Mengajarkan berbagai jenis representasi dan membantu siswa mengartikan beberapa representasi yang berbeda dapat meningkatkan dan mengarahkan pemahaman siswa. Lebih lanjut, memberikan kesempatan siswa untuk menggunakan representasi dan menantang mereka untuk menjelaskan informasi dari representasi yang berbeda dapat mengantarkan mereka ke pemahaman konsep matematika yang lebih dalam (Meredith, 2007).

Sebagai salah satu representasi, diagram mempunyai karakteristik yang khusus yang membedakan diagram dengan representasi yang lain. Karakteristik khusus tersebut adalah penampilan visual dari diagram. Hal tersebut membuat diagram menjadi representasi yang berbeda dari representasi lain. Berdasarkan Curcio (1989) diagram berfungsi sebagai alat untuk mengkomunikasikan dan mengklasifikasikan data. Dengan menggunakan diagram, siswa dapat membandingkan data dan menampilkan hubungan matematis yang seringkali tidak dapat ditampilkan oleh representasi yang lain.

Bentuk diagram yang paling umum yang dapat dengan mudah siswa temukan adalah diagram gambar, batang, garis dan lingkaran. Siswa dapat memulai aktivitas dengan mengkonstruksi dan menginterpretasikan diagram batang dengan memakai ide dan konsep korespondensi satu-satu pada diagram gambar.

\section{Level Kemampuan Siswa dalam Menginterpretasikan Diagram}

Leinhardt, Zaslavsky, \& Stein (1990) berpendapat bahwa kemampuan siswa untuk dapat mengkonstruksi dan menginterpretasi diagram dengan sukses merupakan gabungan dari tindakan, situasi atau konteks dari permasalahan, variabel yang sedang digunakan. Bagaimanapun juga, permasalahan yang diseting dalam penelitian ini bukanlah permasalahan yang complicated, dikarenakan permasalahan tersebut digunakan untuk memperkenalkan siswa akan teknik membaca data pada diagram.

Jones et. al. (2000) merumuskan kerangka pemahaman awal siswa yang didasarkan pada kategorisasi Curcio pada kemampuan siswa membaca diagram yang dikombinasikan dengan perkembangan model dari SOLO taksonomi (Structure and the Observed Learning Outcomes) yang dikembangkan oleh John Biggs dan Kevin Collis. Khusus untuk deskripsi level kemampuan siswa dalam mendeskripsikan diagram dapat dilihat pada tabel 1.1.

Realistic Mathematics Education dan PMRI 
Dalam pembelajaran matematika, Freudenthal (1991) menekankan bahwa siswa harus diberikan kesempatan untuk menemukan dan menggunakan ide mereka sendiri. Dengan kata lain, mereka harus mempelajari matematika dengan cara mereka sendiri. Dia juga berpendapat bahwa matematika adalah aktivitas manusia. Ini mengindikasikan bahwa matematika bukan hanya tentang prosedur perhitungan, akan tetapi, matematika harus di desain dan diajarkan dimana siswa bisa belajar untuk memahami konsep. Oleh karena itu, dalam penelitian ini instructional activities pada pembelajaran diagram dikembangkan. Siswa akan mendapatkan pemahaman yang lebih tentang bagaimana menginterpretasi diagram batang dan garis. Disisi lain, deretan aktivitas yang di desain pada penelitian ini adalah bagian dari learning trajectories yang panjang.

Tabel 1.1. Kerangka berfikir statistik Revisi Jones et. al. (2000)

\begin{tabular}{|c|c|}
\hline & Students' ability in describing data displays \\
\hline Idiosyncratic level & $\begin{array}{l}\text { - Makes no response or an invalid or irrelevant response to the question, "What does } \\
\text { the display not say about the data?" } \\
\text { - Makes no response or gives an invalid or incomplete response when asked to "read } \\
\text { between the data" } \\
\text { - Makes no response or gives an invalid or incomplete response when asked to "read } \\
\text { beyond the data" }\end{array}$ \\
\hline Transitional level & $\begin{array}{l}\text { - Makes a relevant but incomplete response to the question, "What does the display } \\
\text { - Got say about the data? } \\
\text { - impres a valid response to some aspects of "reading between the data" but is } \\
\text { - Gives a vague or inconsistent response when asked to "read beyond the data" }\end{array}$ \\
\hline Quantitative level & $\begin{array}{l}\text { - Makes multiple relevant responses to the question, "What does the display not say } \\
\text { - Gout the data?" } \\
\text { - make multiple valid responses when asked to "read between the data" and can } \\
\text { - Tries to use the data and make sense of the situation when asked to "read beyond } \\
\text { the data"; reasoning is incomplete }\end{array}$ \\
\hline Analytical level & $\begin{array}{l}\text { - Makes a comprehensive contextual response to the question, "What does the } \\
\text { - Gisplay not say about the data?" } \\
\text { - makes multiple valid responses when asked to "read between the data" and can } \\
\text { - Gives a response that is valid, complete, and consistent when asked to "read } \\
\text { beyond the data" }\end{array}$ \\
\hline
\end{tabular}

\section{Metode Penelitian}

Tujuan utama dari penelitian ini adalah untuk memberikan kontribusi pada praktek pembelajaran diagram, yang difokuskan pada kemampuan siswa untuk membaca diagram. Peneliti tertarik untuk mengetahui bagaimana siswa berusaha untuk menemukan arti dari sebuah diagram batang dan garis. Oleh karena itu, design research, dipilih sebagai jenis dan pendekatan penelitian, karena tujuan dari penelitian ini selaras dengan ujuan dari 
penelitian design research. Subjek dari penelitian ini adalah siswa kelas VII A SMP Madinatul Ulum, Jombang, Jawa Timur tahun ajaran 2014/2015. Adapun rancangan yang digunakan terdiri dari tiga tahap (Preparing for the experiment, Experimenting in the classroom, dan Retrospective analysis). Dalam mendesainnya, peneliti mengikuti tiga fase pelaksanaan design experiment yang di definisikan oleh Gravemeijer (1994)

Pada fase Preparing for the experiment, Sebuah HLT (Hypothetical Learning Trajectory) didesain yang meliputi serentetan aktivitas lengkap dengan tujuan matematika (mathematical goals) yang ingin dicapai dan perkiraan pikiran, tindakan, dan strategi siswa (conjectures of students' thinking, actions, and strategies). Sementara itu, pada tahap Experimenting in the classroom, HLT diujicobakan, dan selanjutnya dianalisis dengan cara membandingkan HLT dengan proses belajar siswa yang sesungguhnya. (Retrospective analysis). Data yang dikumpulkan dalam peneltian ini berbentuk hasil kerja siswa dan proses pembelajaran yang divideokan.

\section{Hasil Penelitian dan Pembahasan}

Hyphotetical Learning Trajectories (HLT) yang disusun untuk aktivitas membaca diagram terdiri dari dua HLT (membaca diagram sederhana dan diagram kompleks). HLT tersebut telah diujikan dalam 3 pertemuan. Diagram batang sederhana yang digunakan pada pertemuan pertama adalah diagram batang jumlah penduduk 4 dusun di desa Mojokrapak pada tahun 2012-2104, sedangkan diagram garis sederhana yang digunakan adalah diagram garis nomor sepatu siswa SMP kelas VII. Pada pertemuan kedua dan ketiga, diagram batang kebutuhan siswa dan diagram garis pertumbuhan tinggi anak sampai usia 2 tahun diberikan secara berturut turut. Pada setiap pertemuan, aktivitas kelas dibagi menjadi dua, yaitu diskusi kelompok dan dilanjutkan dengan diskusi kelas. Sebelum diskusi kelompok dilaksanakan, sebuah apersepsi selalu dilakukan.

\section{Membaca diagram batang jumlah penduduk}

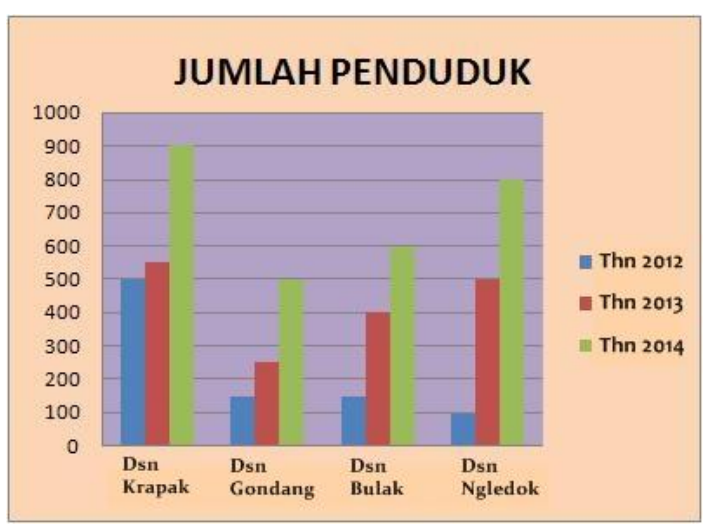

Gambar 1.1. Diagram batang jumlah penduduk

Untuk membaca diagram ini diprediksikan kemampuan siswa akan bervariasi. Sebagian besar siswa akan 
membaca diagram satu persatu dengan menyebutkan nama dusun, tahun, dan jumlah penduduknya. Akan hanya akan ada sedikit siswa yang dapat melihat dan membaca dengan cara menyebutkan selisih, pertumbuhan, jumlah, dan juga menyatakan perbandingan jumlah penduduk dan pertumbuhan satu dusun dengan dusun yang lain. Dalam menentukan jumlah penduduk yang diwakili oleh batang yang tingginya berada diantara dua interval, telah diprediksikan siswa tidak akan mengalami kesulitan yang berarti, selain dalam menyatakan alasan dibalik jawaban mereka.

Dari hasil pengamatan, pada saat diskusi kelompok, semua kelompok membaca satu persatu batang pada diagram batang tersebut, sebagian berdasarkan nama dusun dan sebagian lain berdasarkan tahun. Kemampuan membaca seperti ini sesuai dengan conjecture yang telah ditetapkan. Pada saat diskusi kelompok juga ditemukan beberapa percakapan yang menarik diantaranya tentang cara menghubungkan variable atau label pada sumbu $x$ dengan sumbu $y$ pada diagram batang, cara membaca indeks, skala pada sumbu $y$, dan cara menentukan nilai diantara 2 interval. Pada saat diskusi kelompok, level kemampuan siswa belum bisa ditentukan dikarenakan memungkinkan adanya perbedaan tentang apa yang mereka pahami dengan yang mereka tuliskan. Oleh karena itu perlu dilakukan diskusi kelas.

Untuk membawa siswa pada level yang lebih tinggi, setidaknya siswa mampu menyampaikan apa yang mereka lihat dari diagram, pada diskusi kelas diberikanlah beberapa pertanyaan seputar cara baca, selisih, pertumbuhan, jumlah total penduduk dll untuk mengetahui kemampuan siswa membaca "between the data" dan "beyond the data".

Dengan diskusi kelas, kemampuan siswa dalam membaca "between the data", dapat sedikit ditingkatkan. Hal ini ditandai dengan kemampuan mereka dalam merangkai kalimat, contoh "jumlah penduduk di dusun Krapak pada tahun 2013 berjumlah 550 orang dan pada tahun 2014 berjumlah 900 orang”. Sebuah diskusi yang produktif akhirnya dapat dilaksanakan berdasarkan jawaban siswa tersebut. Pada akhirnya siswa dapat menjelaskan strategi yang mereka gunakan untuk memprediksi nilai diantara dua interval, menentukan selisih, jumlah pertumbuhan, dusun dengan pertumbuhan paling pesat, jumlah penduduk total (seluruh dusun) pada setiap tahun, trend naik untuk setiap dusun dan memperkirakan trend tersebut juga akan berlaku pada tahun 2015. Kemampuan yang terakhir menunjukan kemampuan siswa dalam membaca "beyond the data", 
setelah diberikan pertanyaan yang produktif kepada mereka.

\section{Membaca diagram garis nomor sepatu}

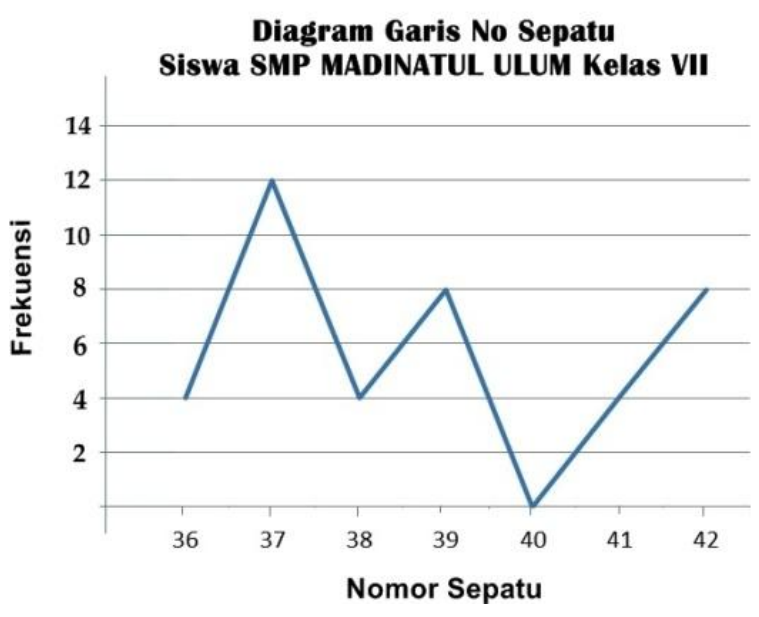

Gambar 1.2. Diagram garis nomor sepatu

Dalam membaca diagram garis nomor sepatu ini, siswa tidak akan mengalami kesulitan yang berarti. Akan tetapi dalam menentukan jumlah siswa yang mempunyai ukuran sepatu 40, sebagian siswa akan sedikit mengalami kesulitan. Dari hasil pengamatan, permasalahan yang dimiliki beberapa siswa adalah kecenderungan mereka untuk selalu membaca hanya dengan cara menyebutkan satu per satu dan kesulitan menyampaikanya dalam kalimat. Bahkan, sebagian siswa yang lain tidak bisa melihat titik, yang nantinya dapat digunakan untuk membaca, pada diagram garis.

Sebuah diskusi kelas, dimulai dengan menunjuk satu anak (Bahrul) dari salah satu kelompok untuk menjelaskan hasil dari diskusi kelompok mereka. Saat berada di depan kelas, Bahrul tidak dapat menjelaskan sama sekali, sampai akhirnya dibantu oleh Tasya, teman sekelompok Bahrul. Dari diskusi kelas tersebut terlihat Bahrul belajar dari strategi yang digunakan oleh Tasya, menentukan titik pada diagram garis yang dapat digunakan untuk menentukan ukuran sepatu (36 dan 37) dan banyak siswa yang mempunyai ukuran sepatu tersebut (4 dan 12).
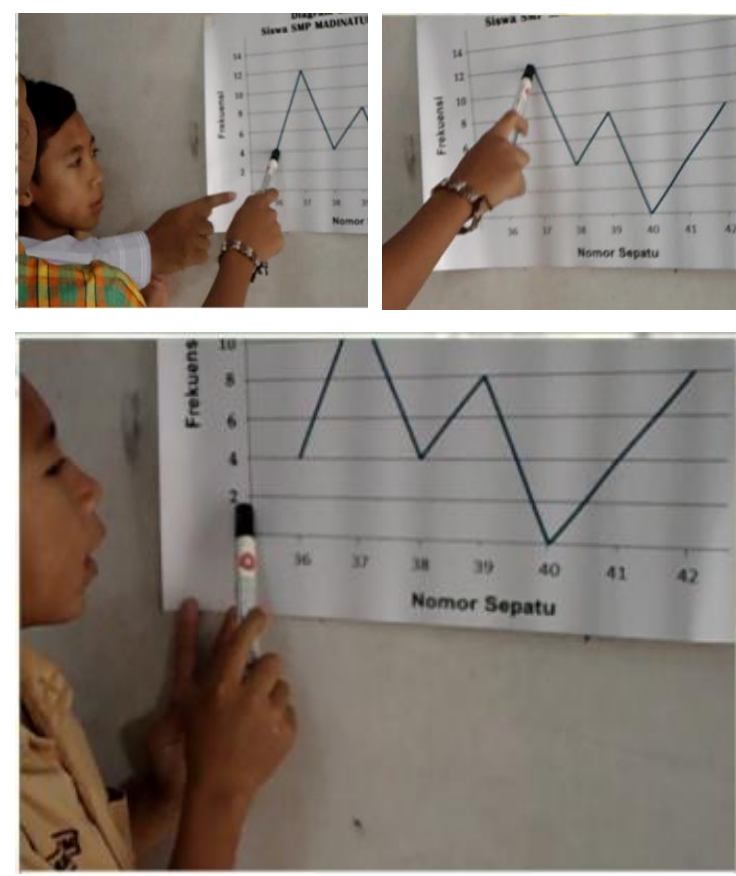

Gambar 1.3. Diskusi kelas untuk membaca diagram garis

Setelah dirasa paham, Bahrul mencoba melakukan hal yang sama untuk menentukan jumlah siswa yang mempunyai ukuran sepatu 38 dan 39. Akan tetapi pada saat menentukan jumlah siswa yang sepatunya berukuran 40, Bahrul terlihat kesulitan dengan menunjuk dan mengganti jawaban dari 2 menjadi 1 . Begitu juga pada saat menentukan jumlah 
siswa yang mempunyai sepatu berukuran 41, Bahrul terlihat tidak tahu dimana letak titik yang harus diamati (mungkin dikarenakan berupa garis lurus). Diskusi ini pada akhirnya mengantarkan seluruh siswa pada pemahaman, bahwa tidak ada siswa yang mempunyai ukuran sepatu 40, terdapat 4 siswa dengan nomor sepatu 41 , dan juga jumlah siswa dalam satu kelas tersebut.

\section{Membaca diagram batang kebutuhan} siswa

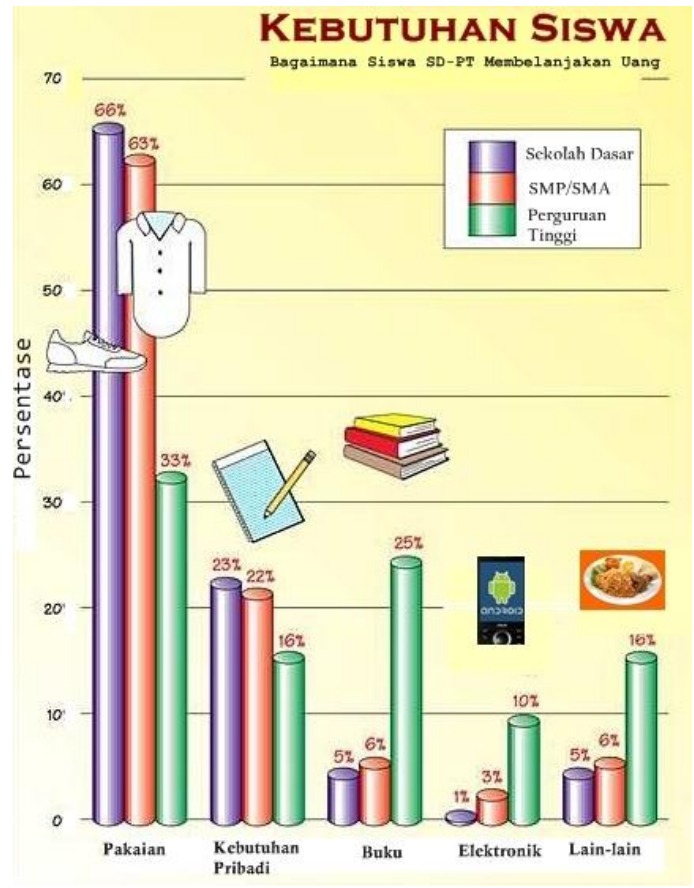

Gambar 1.4. Diagram batang kebutuhan siswa

Sejauh mana siswa mampu membaca diagram batang kebutuhan siswa ini telah diuji, dimana mereka selain diharapkan mampu membaca seperti apa yang mereka lakukan pada diagram batang sebelumnya, juga diharapkan dapat memaknai persentase yang digunakan. Lebih jauh lagi, siswa dapat melihat hubungan jenjang pendidikan dengan jenis kebutuhan mereka.

Sama halnya aktivitas sebelumnya, untuk membaca diagram batang kebutuhan siswa, aktivitas kelas dimulai dengan diskusi kelompok dan dilanjutkan dengan diskusi kelas. Dari segi aktivitas belajar, terlihat perubahan pada beberapa siswa. Terdapat beberapa siswa yang tanpa ditunjuk, berani mengangkat tangan untuk mengemukakan pendapat dan atau maju untuk menjelaskan. Hal seperti ini tidak terlihat pada pertemuan sebelumnya.

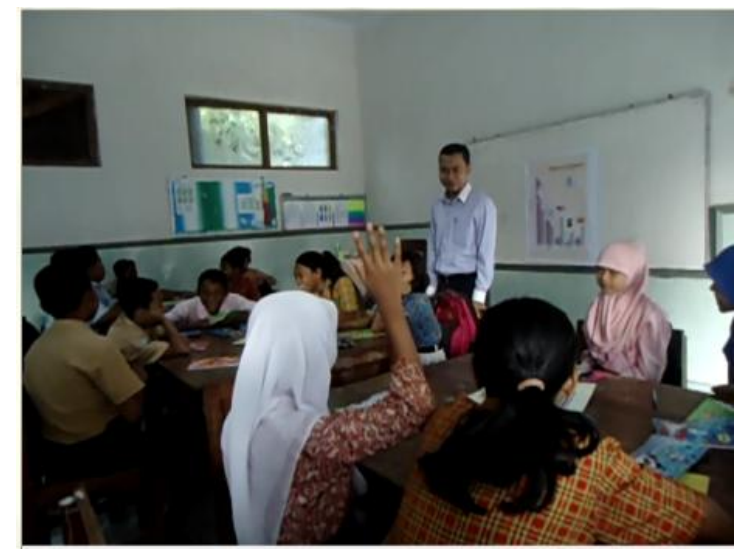

Gambar 1.5. Siswa menjadi volunteer untuk maju

Dari sisi kemampuan mereka dalam membaca diagram batang, masih terdapat beberapa siswa dalam kelompok yang membaca dengan cara satu-persatu berdasarkan jenis kebutuhan atau tingkat pendidikan siswa. Akan tetapi terdapat juga kelompok yang membaca berdasarkan jenis kebutuhan yang paling 
tinggi untuk tiap-tiap tingkat pendidikan dan kelompok yang mencoba memberikan alasan dari jawaban mereka.

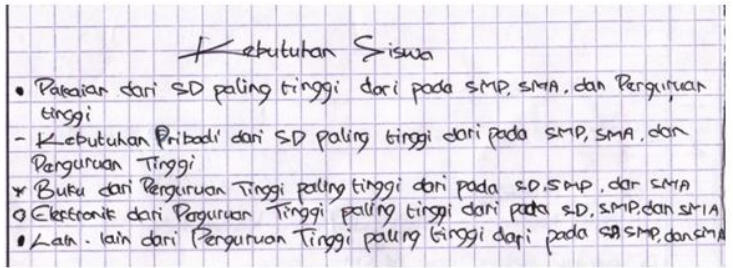

(a)

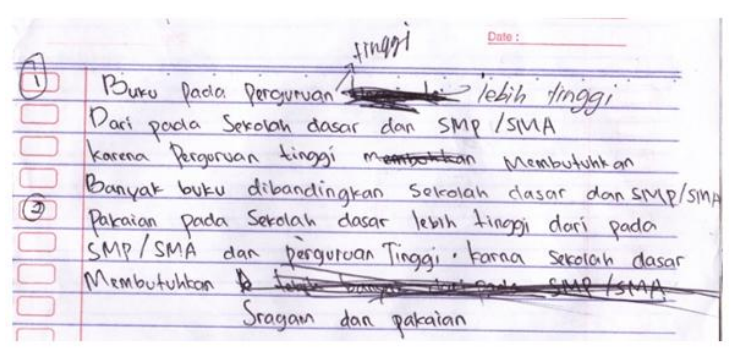

(b)

Gambar 1.6. Hasil diskusi kelompok membaca diagram batang kebutuhan siswa

Kedua jawaban di atas, untuk selanjutnya dijadikan bahan diskusi kelas. Jawaban siswa pada gambar 1.6. (a) dijadikan sebagai bahan untuk mendiskusikan bagaimana cara membaca "between the data" yang mengantarkan mereka pada pemahaman total persentase untuk masing-masing tingkat pendidikan adalah $100 \%$. Pemahaman ini menginspirasi mereka untuk membaca data dengan mengacu pada $100 \%$ tersebut. Selanjutnya, jawaban siswa pada gambar 1.6. (b) telah dijadikan bahan diskusi kelas untuk membaca "beyond the data". Walaupun prediksi alasan itu belum tentu benar, akan tetapi siswa sudah mulai mengembangkan strategi dalam membaca diagram dengan cara yang berbeda. Sebuah tahapan awal menuju quantitative level.

\section{Membaca diagram garis pertumbuhan anak sampai usia 2 tahun}

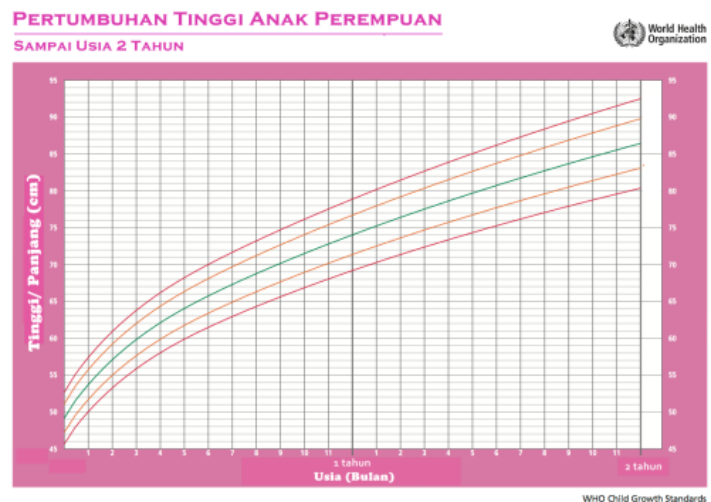

Gambar 1.7. Diagram garis petumbuhan tinggi badan

Dengan hanya mengacu pada garis berwarna biru (tinggi badan rata-rata), pada aktivitas ini, siswa diperintahkan untuk memahami dengan seksama apa yang mereka pahami dari diagram tersebut. Dikarenakan pada aktivitas sebelumnya siswa sudah mulai mengembangkan strategi mereka untuk membaca sebuah diagram, maka pada aktivitas ini diprediksikan beberapa siswa dapat dengan mudah menentukan tinggi badan anak perempuan pada usia tertentu dan belum ada siswa yang mampu menyampaikan baik secara tertulis maupun lisan. Oleh karena itu beberapa pertanyaan sudah dipersiapkan diantaranya "apakah kalian tahu berapa 
cm pertumbuhan tinggi badan dari lahir sampai usia 2 tahun?" dan "dapatkah kalian memprediksikan pertumbuhan tinggi anak perempuan setelah 2 tahun?"

Data yang didapatkan dari proses diskusi kelompok mengindikasikan bahwa seluruh siswa telah mampu membaca satu persatu data sesuai dengan usia, sebagian siswa dapat melakukan pengurangan tinggi badan dari dua usia yang berbeda, namun belum belum mampu memaknai proses pengurangan tersebut dan memaknai 0 bulan. Oleh karena itu pada saat diskusi kelas. Siswa diarahkan untuk memaknai 0 bulan sebagai tinggi anak disaat dilahirkan. Sementara itu, pertanyaan "apakah kalian tahu berapa cm pertumbuhan tinggi badan dari lahir sampai usia 2 tahun?" mengantarkan mereka pada pemahaman pertumbuhan tinggi badan dalam kurun waktu tertentu. Yang didapatkan dengan cara melakukan pengurangan.

Sebagai akhir dari diskusi kelas, pertanyaan "dapatkah kalian memprediksikan pertumbuhan tinggi anak perempuan setelah 2 tahun?" berfungsi mengantarkan mereka pada pemahaman trend diluar data, dan trend tersebut akan berhenti pada usia tertentu.

\section{Penutup}

Cara siswa dalam membaca informasi pada diagram batang dan garis cenderung dengan menyebutkan satu per satu pasangan label pada sumbu $x$ dan $y$. Kemampuan tersebut berada diantara Idiosyncratic dan Transitional level. Akan tetapi sulit untuk memastikan berada di level mana kemampuan siswa tersebut, dikarenakan apa yang mampu mereka pikirkan berbeda dengan yang telah mereka tulis. Dari diskusi kelas, terlihat jelas kemampuan mereka dalam membaca lebih tinggi (dan juga berkembang) dari yang mereka tulis atau diskusikan di kelompok. Ini terlihat dari cara mereka menjawab beberapa pertanyaan produktif pada saat diskusi kelas. Dari data yang didapatkan menunjukan siswa mulai berada pada Quantitative level.

Dari serangkaian proses pembelajaran, perevisian HLT yang didesain perlu untuk dilakukan, dikarenakan ada beberapa conjectures yang tidak sesuai (tidak terjadi atau tidak terprediksikan) dan penentual goals dari masing-masing aktivitas membaca diagram. Hal ini ditujukan agar kemampuan siswa membaca diagram dapat lebih ditingkatkan jika HLT dibuat berdasarkan cara siswa belajar.

\section{Pustaka}

Ates, S. \& Stevens, J. T., (2003). Teaching line graphs to tenth grade students having different cognitive development levels by using two 
different instructional modules. Taylor \& Francis Ltd.

Curcio, F. R. (1989). Developing graph comprehension. Reston, VA: National Council of Teachers

Ersoy, A. F. (2004) The effects of calculator based laboratories (cbl) on graphical interpretation of kinematic concepts in physics at metu teacher candidates. a thesis submitted to the graduate school of natural and applied sciences of middle east technical university

Freudenthal, H. (1991). Revisiting Mathematics Education: China Lectures. Dordrecht: Kluwer Academic Publishers. Gravemeijer, K., \& Cobb, P. (2006) Design research from the learning design perspective. Educational design research (pp. 17-51). London: Routledge
Gravemeijer, K. (1994). Developing Realistic Mathematics Education. Utrecht: CD Beta Press.

Jones, G., A., \& Thornton, C., A., Langrall, C., W., \& Mooney, E., S., (2000). A Framework for Characterizing Children's Statistical Thinking. Lawrence ErlbaumAssociates, Inc.

Leinhardt,G., Zaslavsky, O., \& Stein, M. K., (1990). Functions, graphs, and graphing: tasks, learning, and teaching. American Educational Research Association

Meredith, A., Rogers, P., Volkmann, M. J., \& Abell, S. K., (2007). Science and mathematics: a natural connection

Parmar, S. R. \& Signer, B., (2005). Sources of error in constructing and interpreting graphs: a study of fourth-and-fifth-grade students with LD. Journal of Learning disabilities 